\title{
Politeness Strategies Used by Youth in Their Language Use
}

\author{
Francis Kariithi
}

\begin{abstract}
The aim of this study was to investigate politeness strategies that are employed by youth while communicating with other members of society. It is a known fact that, youth have been castigated for lacking decency while addressing issues that may be perceived to be obscene in nature such as deaths, diseases, different functions of body parts, sexual matters, just to mention a few. Despite unprecedented complaints on the manner by which some youth use their language, this study set out to denounce that old folk by unearthing the various politeness strategies that Kenyan youth engage in while communicating with different groups of people. This study established that the language that is often used by the youth carries politeness elements in different levels during their communication; with such evidence in place, politeness in the youth language use was absolute. Descriptive method of data analysis was relied on. Purposeful sampling design was used with the researcher using questioners. The questions were aimed at identifying researcher respondent's level of language use sensitivity in line with the purported obscene language use. Because the study intended to investigate youth politeness strategies; the researcher relied on Brown and Levinson Politeness Theory. Sampling was done from 30 respondents from 3 secondary schools in then Nakuru Municipality. There were 15 female students and 15 male students. The study established that youth use assorted set of politeness strategies in their language; in essence, the study found out that the said politeness strategies are assigned differently depending on the social class of the speaker and the recipient, discourse topic involved, context and more importantly the reason behind their communication
\end{abstract}

Key Words; Politeness Strategies

\section{Introduction}

Youth population in Kenya account for approximately 63\%; UNESCO (2004), and as such any effort made to understand them is of paramount importance; in view of the above observation, the manner in which youth use their language has always attracted varied sentiments, with some terming youth language use as uncouth more specifically when taboo language is concerned. This study set out to unearth the various politeness strategies that are employed by youth in their language use.

\section{Literature Review}

Njeri (2007) in her study observed that politeness and language use, and its appropriateness in matters involving discourse topics on HIV are at juxtapose; hence need to be polite while conveying such intricate matters within the society. In essence, among the Gikuyu community there will always emerge varied attitudes on when and how polite language use should play out. Njeri (2007) targeted HIV in relation to how information involving it could be decoded. In this study, the researcher acknowledged one crucial part that youth play while relying information on such matters that happen to be delicate not only to the youth, but also to the old and young alike. With such matters in the picture, there was need to evaluate various politeness strategies that youths employ during their discussions.

Wambua (2009) evaluated the nature of taboo language in connection with polite language use by confining himself to the attitude exhibited by some sub-tribe among the Kamba language group. He investigated whether difference in sex, age, and difference in language sub-tribe among the Kamba community had effect on peoples' attitude, and if the choice of the said words could find its way back in the discussion. While quoting a certain scholar in Nigeria, Igboanusi (2001) observed that polite language has always directed attitude. In this study therefore, there was need to interrogate whether youth language is always directed by attitude alongside politeness strategies. Mbaya (2000) in Nordic African Studies Journal investigated taboo language usage in marriage context; Laguu, involving Oromo community. He said that, in order for decency to thrive between a husband and a wife, different strategies are employed in order to fill the gap, and therefore improving intermingling between them.

Buliba et al (2006:88) observed that there is serious relationship between language, society and culture because since time in memorial language in many cultures has shown that even though certain words have not been banned; their usage is valid only in certain forums and by certain class of people. In essence, communities in many areas embrace use of language that advocate for positive moral order. Other forms of taboo language try to prohibit or to delete certain aspects in language. In view of the above, it is clear to cite that youth on their 
part have certain aspects of politeness in language use that they hold dear - strategies of politeness in language use.

Hudson (1995) investigated the relationship that is there between language and society where he discovered that there are varying strategies that are employed by different groups of people according to their classes while communicating. He cited that; that will change in accordance to peoples' social status change. He retaliated that workers in a given place will always have their different way of communicating from another groups.

Whilst quoting Fromkin and Rodman (1988), Njeri (2007:20) observed that society formulate words when they are in a process of growing and later consensus is reached on regarding category of polite words which are termed as obscene - obscene words are finally tagged, and they are never used anyhow. The aforesaid scholar go further to observe that, all words are made of man, but society's context will always turn to be the deciding factor on where the said word is to be used. They continued to say that, 'language obsceneness or appropriateness has its place in the ear of the listener or the entire society observation.

\section{Objective of the Study}

The objective of the study was to examine politeness strategies used by youth in their language.

Research Question

What are the politeness strategies used by youth in their language use?

\section{Methodology}

This study employed descriptive data analysis method. According to Orodho (2003), descriptive data analysis is usually relied on by researchers because it can give researchers time to collect data, to condense data, to interpret and present. Sampling of data was purposeful, since, as observed by Patton (1990:169); the logic and power of purposeful sampling lies in selecting information-rich cases for study in depth. Questioners were used where the researcher had 30 respondents from three secondary schools in the then, Nakuru municipality. There were 15 male students and a similar number for female students. In analyzing data, respondents' response was assigned to Brown and Levinson (1987) Politeness Theory strategies. In order to have a conclusive analysis, frequency on respondents in relation to each strategy was employed.

\section{Findings And Discussions}

Pragmatics in this research was of central importance because of one vital interest; that of tying meaning on findings with the politeness strategies as observed by the proponents of that theory, Brown and Levinson (1987). In connection to the data, this study found out that youth employ varying politeness strategies in their language while communicating depending on the composition of their audience. The said politeness strategies are tailored in response to discourse topics, prevailing context and the nature of one's' audience set up. Brown and Levinson sum up human politeness behaviour in four strategies: bald on record, negative politeness, positive politeness, and off-record-indirect strategy.

The bald on-record strategy does nothing to minimize threats to the hearer's "face" investigation led to assigning a number of youth use of language in line to this;

Question: A male or female friend finds you flirting with your boy or girl friend; what will be your response?

Response: 1) Ha! Ha! Ha! Let us assume that it never happened

2) I was only releasing steams.

Observation: Due to the cordial relationship that may have been there, it was indeed clear from the response to conclude that FTA in such contexts was of no consequence.

The positive politeness strategy shows you recognize that your hearer has a face to be respected. It also confirms that the relationship is friendly and expresses group reciprocity.

Question: Suppose you find your mother seated with her pants exposed to anybody entering your seating room; how will you react to that occurrence?

Response: 1) (Male Students) I will not say anything, 2) I will tell her that she is being called by my father, 3) I will leave immediately.

2) (Female Students) 1) I will bring her a khanga/kikoi, 2) Mum your dress is too short.

Observation: My respondents' response indicated clearly that they cared for the positive face of their mothers. A number of students' response indicated that they were lying politely. 
The negative politeness strategy recognizes the hearer's face, but it also admits that you are in some way imposing on him/her.

Question: As a male student, you feel attracted to a female student; how will you break your silence?

Response: 1) Excuse me please... can you spare two minutes for me? 2) I don't want to offend you, can I talk to you? 3) I don't want to bother you but, would it be possible for me talk to you?

Observation: It is clear from the aforementioned observation to conclude that, youth recognises one fact; that when conditions dictate they must apply positive strategies.

Off-record indirect strategies take some of the pressure off. Here one tries to avoid the direct FTA.

Question: You realize your colleague's shoes are not polished and he or she knows that you have seen it. How will you behave?

Response: Please could you use my shoe polish before you buy some...

Observation: Most youth realized that it would rather it was offered to you once your colleague sees that you need some, than for them to ask to be assisted.

\section{Conclusion}

In conclusion, this study revealed that youth employ varied politeness strategies in accordance with prevailing circumstances such as social class of their audience, age, context, relationship and their reason for the said communication. As it has been noted, youth could opt for any strategies such as, bald on record, negative politeness, positive politeness, and off-record-indirect strategy. Selection of one politeness strategy instead of the other was meant to address one given groups' need.

\section{References}

[1]. Brown, P. and S. Levinson (1987) Politeness: Some universals in language usage. Cambridge: Cambridge University Press.

[2]. Buliba,A, Njogu, K and Mwihaki, A (2006) Isimujamii kwa wanafunzi wa Kiswahili. Nairobi: Jomo Kenyatta Foundation.

[3]. Carter, R and McCarthy,M (1994) Language and discourse - perspective for Language Teaching. New York. Longman Publishing,

[4]. Fromkin, V. Rodman, R (1988) Introduction to Language. Holt: Rinechart and Winston.

[5]. Fromkin, V. Rodman, R. and Hymes, N. (2003) An Introduction to Language. ( $7^{\text {th }}$ Ed) Boston: Wardsworth Thompson Corporation

[6]. Hofmann, R (1993) Realms of Meaning, an introduction to semantics. London: Longman.

[7]. Hudson (1995). Language and Society. London: Macmillan Publishers.

[8]. Igboanusi, H. (2001) LanguageAttitude and Language Conflicts in West Africa. Ibadan: Enicrowfit Publishers.

[9]. Leech, G. (1983) Principles Of Pragmatics. Singapore: Longman Publishers.

[10]. Mbaya. M (2002) Linguistic Taboo In African Marriage Context: A Study Of The Oromo Laguu. Nordic Journal of African Studies 11(2): 224-235 Senegal: University of Gaston Berger.

[11]. Njeri,S (2007) A pragmatic Analysis of Gikuyu Lexical euphemisms in HIV/AIDS Discourse. Unpublished MA Thesis, University of Nairobi.

[12]. Orodho, A. J (2003) Essentials of Education and Social Science Research Methods. Nairobi: Masola Publishers.

[13]. Patton, M. (1990) Qualitative evaluation and research methods (pp. 169-186). Beverly Hills, CA: Sage.

[14]. http://legacy.oise.utoronto.ca/research/field-centres/ross/ctl1014/Patton1990.pdf 29/10/2010

[15]. UNESCO's Participation in the World Youth Festival, Barcelona 2004 Maria-Helena Mueller, UNESCO Bureau of Strategic Planning, Section for Youth.

[16]. Wambua, R. S (2009) Variation In Dialect Use Of And Attitudes Towards Taboo Words And Euphemisms In Kikamba. Unpublished MA Thesis, University of Nairobi. 